\title{
O AUSTERO CAMINHO DA POLÍTICA CLIMÁTICA SEGUNDO GIDDENS
}

\author{
GIDDENS, Anthony. A política da mudança climática. Rio de Janeiro : Zahar, 2010. 314 p.
}

Não haver atalhos para a solução dos grandes problemas ambientais parece ser um dos muitos recados que Anthony Giddens, em sua obra "A Política da Mudança Climática", pretende manifestar ao leitor. A solução encontra-se, por sua vez, na intensa "transpiração política" mundial para com relação ao tema, na forte necessidade de convergência política do globo e na imprescindível boa vontade política para com a questão. A invocação do desenvolvimento de novos métodos e novas tecnologias não é, no decorrer de toda a obra, desvinculada da disposição política exigida no trato com o problema, disposição política esta que é necessária e que provenha das altas esferas do poder geopolítico do planeta. A obra de Giddens diminui muito uma clássica ideia difundida do escopo ambiental de que a solução da questão ambiental virá de "baixo para cima", mas, ao contrário, o autor insiste de que ela virá dos governos, sejam eles democráticos ou não.

A questão ambiental, em especial para com a questão da intensidade de emissão de gases estufa, é apresentada com o grau de dramaticidade que normalmente lhe é característico. Contudo, Giddens a coloca em um patamar de austeridade governamental, comentando friamente as possibilidades e os duros obstáculos que serão enfrentados. O Estado é novamente recolocado em sua posição central de poder, poder necessário para se conseguir possuir forças para a evolução e consolidação das soluções. Para este Estado e para os seus integrantes, sejam eles eleitos ou não, o autor faz as seguintes considerações: os líderes políticos devem pensar as políticas antecipando os possíveis grandes problemas, planejando em longo prazo; estes políticos devem aprender a lidar com os riscos deste processo vinculado as mudanças climáticas e ao setor energético, que por sua vez encontra-se no contexto de outros riscos relevantes à sociedade; consolidar a existência do imperativo da necessidade da convergência política e econômica mundial e concretizar a importância do princípio do "poluidor-pagador". O autor também insere, como princípios de primeira necessidade do Estado: agir contra os interesses empresariais que não estejam aderindo às iniciativas referentes às mudanças climáticas; manter o assunto referente às mudanças climáticas no topo da pauta de discussões e objetivos políticos; desenvolver uma estrutura econômica e fiscal estruturada e regulada a uma economia com baixo teor de carbono; confirmar a necessidade mundial de preparação para a adaptação às consequências vindouras da mudança climática; e por fim, integrar os aspectos legais de escalas regionais, nacionais e internacionais da política da mudança climática.

O autor coloca, de maneira enfática, de que a figura do Estado, antes enfraquecida pela influência da corrente neoliberalista, especialmente dos anos de 1990, tem obrigatoriamente e estrategicamente de reassumir a sua posição como tomador principal das decisões. Todavia, Giddens não desvaloriza o setor privado, sendo este detentor de um poder que não pode ser ignorado, e devido à natureza do discurso de característica convergente do autor, nem o poderia. Com a revalorização do Estado, se revaloriza, consequentemente, os esforços em um planejamento político das ações, sejam elas nas esferas macrorregionais, mesorregionais e microrregionais, planejamento este que, como todo o esforço do que se conceitua como planejar, não pode levar somente em consideração a valorização de novos métodos e de novas técnicas, mas também deve se pautar pela sua capacidade e detalhamento logístico, pelo seu zelo para com o monitoramento e gerenciamento dos problemas referentes à questão, pela sua capacidade de promover uma mudança dos hábitos e da educação social e pela sua preocupação com o seu escopo moral e ético.

O autor, em toda a obra, ressalta a complexidade espinhosa da questão climática no contexto geopolítico do globo, a lentidão das ações políticas ambientais entre os países, mesmo com o surgimento de novas ideias e de novos métodos, e a urgência gradualmente mais exacerbada por mudanças em um mundo mais próximo das sombrias previsões de aquecimento global verificadas. Giddens também reafirma sua posição epistemológica favorável aos cenários apresentados pelo IPCC, mesmo não desvalorizando a parcela "cética" dos cientistas referentes ao aquecimento global de origem antrópica. Critica a manutenção do setor energético 
tradicional embasado na utilização dos combustíveis fósseis e igualmente debate sobre o porquê dos setores produtivos estarem ainda muito tímidos com relação ao desenvolvimento de fontes de energia alternativa. Também é realizada, ao longo da obra, uma discussão sobre o conceito de desenvolvimento sustentável, em que, para o autor, trata-se mais de um lema ideológico do que propriamente uma possibilidade, mesmo porque considera o próprio conceito difícil de ser conceituado, pela sua natureza altamente generalista e "escorregadia". Convém também mencionar o esforço do inglês em explicar a trajetória da formação e consolidação "dos verdes" ao longo das décadas de 1970 até os dias atuais, procurando "desmistificar" alguns aspectos deste movimento, inserindo-os como um importante grupo ideológico e político, mas tão detentores de desejos e de metas de poder como qualquer outro grupo político.

Deve ser valorizado o grande leque de exemplos que o autor coloca, com relação ao histórico de tentativas que estão sendo efetuadas no desenvolvimento de novas tecnologias que estão fortalecendo a própria política climática, tais como iniciativas que foram ou estão sendo aplicadas em países como a Suécia, Noruega, Islândia, Dinamarca e Finlândia, pais enquadrados como os detentores da vanguarda nestas ações. Além da vanguarda, Giddens enumera a importância geopolítica de outros países-chave para com a questão ambiental, tais como: o Reino Unido, os Estados Unidos, a China, a Índia, o Brasil, dentre outros.

Em todo o livro percebe-se o esmero diplomático no trato para com as questões ambientais no ramo da política e, ao mesmo tempo, a necessidade aguda de revelar ao leitor que a questão vai muito além de mudanças metodológicas ou técnicas que devem ser efetuadas no setor infraestrutural da produção econômica. A política da mudança climática constitui-se, por sua vez, em uma "arena de luta" das nações desenvolvidas e das nações em desenvolvimento, onde "em meio à batalha" surgem os clamores das nações subdesenvolvidas, ou, como o próprio autor coloca, o "bilhão inferior". Entre este árduo centro de conflitos, surge o setor privado, ainda fortemente atrelado aos moldes de produção clássicos de um sistema filosoficamente em crise. Na luta dos Estados e seus interesses, todavia, surge de maneira conflitante os anseios de uma sociedade que observa as ações dos representantes que teoricamente estão lá para representá-la.

A elegância britânica de Giddens não permite apresentar, escancaradamente, as mazelas dos interesses, muitas vezes mesquinhos, de poder dos representantes dessa elite mundial detentora deste poder; interesses que, mesmo que englobem o cotidiano de milhares de pessoas, não possuem como seu fim a evolução e a perpetuação de uma humanidade e a proteção das gerações vindouras, mas a continuidade predatória de um modelo de produção que ainda encontra-se viciado na supervalorização do lucro.

Mas enquanto o mundo, entre as principais conferências ambientais mundiais, trabalha exaustivamente na busca de "uma equação mágica" que ofereça condições para este mundo não promover demasiados conflitos no partilhamento racional das responsabilidades ambientais das nações que, por sua vez, introduza algumas mudanças nos aspectos econômicos de um sistema estruturalmente injusto e formador de desigualdades, renovando as esperanças de uma sociedade que almeja crescimento com qualidade e com inteligência, 0 planeta gradativamente se aquece, as mudanças climáticas vão se tornando mais agudas e abruptas e os povos, particularmente os mais pobres, encontram-se mais vulneráveis e ameaçados. No furor dessa arena de conflitos, parece surgir, na obra em questão, a voz de um inglês clamando por um pouco de ordem, bom senso e racionalidade política.

André Geraldo Berezuk - UFGD 